\title{
HAUGHT, GOLSHANI AND THE SCIENTIFIC VIEWPOINT OF STATE ISLAMIC UNIVERSITY IN INDONESIA
}

\author{
Muhammad Thoyib \\ College of Islamic Studies (STAIN) Ponorogo \\ Jl. Pramuka, No.156 Ponorogo-East Java-Indonesia \\ E-mail: thoyibmuhammad99@yahoo.co.id
}

\begin{abstract}
This article aims to examine the scientific view of the State Islamic University in Indonesia, namely, the concept of 'integration of science and religion'. The theory used is based on 'theology theory of evolution' of John F. Haught and theory of Islamic Science of Mehdi Golshani. State Islamic University such as UIN Sunan Gunung Djati Jakarta, UIN Syarif Hidayatullah Jakarta and other UIN, authorized open course, both of science humanities, social, technical and religious faculty. Referring to the Haught and Golshani's views, there are three approaches in the development of Islamic science in UIN; First, science aims to find the meaning of Allah (ontological); second, dismantle and re-test the findings of the medieval Islamic scientists (epistemological); Third, utilizing science to build a better civilization (axiological). Thus, UIN's existence in the future is largely determined by the success or failure of these institutions to develop the three areas of science Islam.
\end{abstract}

Keywords: Integration, Science, Religion, State Islamic University

\begin{abstract}
ABSTRAK
[Artikel ini bertujuan mengkaji pandangan keilmuan Universitas Islam Negeri di Indonesia yaitu konsep 'integrasi sains dan agama'. Teori yang digunakan untuk membahasanya adalah 'teori teologi evolusi' dari John F. Hanght dan teori Sains Islam dari Mehdi Golshani. Universitas Islam Negeri seperti UIN Sunan Gunung Djati Bandung, Syarif Hidayatullah Jakarta dan UIN lainnya, diberi kewenangan membuka program studi, baik sains humaniora, sosial, teknik, keagamaan dan kealaman. Merujuk kepada pandangan Haught dan Golshani, ada tiga pendekatan pengembangan sains Islam di UIN; pertama, sains bertujuan mencari makna Allah swt (ontologis); kedua, membongkar dan menguji coba ulang temuan para saintis Islam abad pertengahan (epistemologis); ketiga, memanfaatkan sains untuk membangun peradaban yang lebih baik (aksiologis). Berarti, eksistensi UIN di masa depan sangat ditentukan oleh berhasil tidaknya lembaga ini dalam mengembangkan tiga wilayah sains Islam tersebut].
\end{abstract}

Kata Kunci: Integrasi, Sains, Agama, Universitas Islam Negeri

\section{INTRODUCTION}

This paper is an attempt to explore significant issues emerging in scientific development with correlation to an effort of strengthening the Islamic Higher Education (Perguruan Tinggi Agama Islam) in Indonesia; that 
is about the integration of Science and Religion, particularly in the context of the development of Science and Technology that is rapidly increasing now. The change of several State Islamic Higher Educations (PTAIN), such as State Islamic Institute (IAIN) becomes the State Islamic University (UIN), is one of the tangible evidence of how the encounter of two entities of knowledge (Religion and Science) has resulted in a process of metamorphosis that is very interesting to be analyzed. On the other hand, many Islamic Higher Educations (including Private Islamic Higher Education/PTAIS) that provide public courses such as psychology, sociology, engineering and others during this postscript viewed as 'deviant' from Islamic Higher Education philosophical foundation itself and it is a proof that the process of metamorphosis has been 'infected' Islamic Higher Education (PTAI) in Indonesia. A pretty deep anxiety is how to interpret integration itself and this study (research) is an attempt to understand the contemporary integration of Religion and Science well and comprehensively.

The author traces the dimensions of integration with dismantling the thought of two influential scholars at this time. The figures are John F. Haught and Mehdi Golshani. John F. Haught is a Christian theologian of the United States who is often referred as one of the leading systematic theologians. While, Mehdi Golshani is an Iranian physicist who in recent times begins to show great attention to Religion, especially when he struggled to correlate Science to Religion which he believes in. The choice of study on John F. Haught and Mehdi Golshani's thought is because of their recent strong influence in the integration discourse, both in the West and in the East. Besides, the two figures are quite realistic in locating Religion intersecting with Science. Both of them closely follow the development of Science, but at the same time they still remain critically and stay being religious men. It is a kind of difference from the thought that tend to try to force Science to return in pristine shape as idealized by Seyyed Hossein Nasr. Against such that, the integration project between Science and Religion is expected to become a trending big project ahead (futuristic orientation).

This paper comprehensively outlines a few basic things of the thought of Haught and Golshani. To facilitate the tracking more easily, in every character it explores, it is approached by four basic thing discourses: First, it shows how Religion and Science are interpreted by each character (either Haught or Golshani) and what happens when Religion should meet with Science; whether Science and Religion look hostile glasses (conflict), aloof but not hostile to each other, exchange mutually equal, or even merge with each other and unite themselves? Second, combining the basic assumptions used by Haught and Golshani in integrating Science and Religion. This assumption is an important part that can integrate scientific justifications 
with descriptions of Religion. Third, it discusses thediscourse of the real form of integration where John F.Haught offers a Theology of Evolution and Mehdi Golshani with Islamic Science. This description would clarify the form (model) of integration offered. The third pattern is the approach chosen to facilitate the mapping of thought as well as the materials to be able to see with clarity of thoughts that proposed by each scholar. Finally, this paper connects and at the same time combine the two men thought in the context of the development of Islamic higher education (IHE) in Indonesia, with the hope of Islamic Higher Education (PTAI) in Indonesia can be more acceptable and dynamic in with the times, without losing its vitality roles as an institution of Islamic education committed to the development of Islamic values in the stage of world civilization. Borrowing the language ofRahman (1996, p. 27), Islamic Higher Education (PTAI) is not just participant, but more than that, as one of the driving forces of world civilization that is able to 'grounded' as well as 'offers' the values of rahmatan lil 'álamin more elegant, so it is able to survive continoually and exist in today's global competition.

\section{DISCUSSION}

John F. Haught is a Roman Catholic theologian in USA as well as a Senior Research Fellow at the Woodstock Theological Center at Georgetown University. His area of expertise is systematic theology, with a special interest in issues of Science, cosmology, ecology, and reconciling evolution and Religion. Haught testifies against teaching intelligent design in schools because of religious nature in the case of Kitzmiller Dover Area School District. He was also involved with a controversy on the publication blocking the video of the public debate related to the compatibility of Science and Religion. As the founder of the Center for the Study of Science and Religion at Georgetown, he became the Chairman of the theology department of Georgetown from 1990 to 1995. At his creationic evolution, Haught's views on Science and Religion are at two different levels, but the explanation is not competing one to another, while emphasis on"Science and Religion can not logically exist in a competitive relationship with each other.".Haught graduated from St. Mary Seminary University in Baltimore and later received his $\mathrm{PhD}$ in theology from The Catholic University of America in 1970. He is the winner of the Owen Garrigan Award in Science and Religion in 2002 and Sophia Award in 2004 for Theological Excellence. In addition, in 2009, in recognition to his work on theology and Science, he was awarded a Doctorate Honoris Causa by the University of Leuven (Haught, 2000,p. 315).

In the same context with Haught, Mehdi Golshani is an influential scholar and a Muslim expert in the field of Physics. He was born in Isfahan, Iran in 1939. He completed his undergraduate degree from the University of 
Tehran with a specialization in Physics in 1960 while he also obtained his $\mathrm{MA}$ and $\mathrm{PhD}$ from University of California in the same field of study, Physics. During his career as an academics, he has produced more than 20 books and 100 international scientific articles which are so appreaciable leading him to get a number of individual awards, both academic and governmental ares. Among the major awards he earned as the professor of Sharif University of Technology, Iran Tehran is the John Templeton Award for Progress in Religion (World's Largest Monetary Award) in 2002, and so forth. His idea of the magnitude of the Islamic Saince is so visible in the 2 landmark works; The Holy Quran and the Science of Nature and Can Science Dispense with Religion? It took him to the height of the popularity of international academics which was highly respected by the scientists of the world.

\section{The Integration of Science and Religion in the Perspective of Haught}

Haught (2000, p. 31) divides the relationship patterns of Science and Religion in four forms; 1). conflict, 2). contrast, 3). contact, and 4). Confirmation. The first relation places Science and religion as two opposing entities at different angles; contentially, historically, and methodologically. In this relationship the pattern flowsin the corridor of scientific skeptics as power which strongly affirms no necessary religious explanations anymore with literal group (Biblical Literalist) who understands the Bible as the only source of truth. In encountering of two different entities, it is mutually asserted that conflict raises no denouncement.

In contrast relation, Haught (1995, p. 21) suggests to make a clear distinction between Science and Religion so there is no conflict. This restriction is intended as an explanatory that each has a different area, so it should not justify Religion, for example, with the categories that are owned by Science. This contrasting pattern of relationships is important because conflicts often arise when there is 'fusion' (conflation), namely the collapse of differences of Science and Religion as the result of the loss elements that distinguish the two. Of course, this 'fusion' (conflation) occurs, both in Religion and Science. The death punishment of Galileo's story was an error of identifying Religion areas that are imposed on the Science.

The next pattern is contact. With this relation, Religion and Science are directed to communicate each other without losing its boundaries. This departs from the fact where they often meet and mutually are conditioned to express their own opinions.

The last form of relationship, which clearly indicates the main project of Haught, is confirmation. He defines confirmation as 'strengthening' or 'support, that Religion is fully support to the efforts of understanding the 
universe undertaken by Science. In other words, he says: "Religion is in a very deep way supportive of the entire scientific enterprise," (1995, p.21). The confirmation form of integration of Religion and Science is not because Religion provides a set of knowledge about the universe such as those offered by Science; religion does not provide details of knowledge about particle physics or genetic code. This attitude is due to principally support the views of Religion about the universe is limited, coherent, rational, and regularly, providing a common view of consistently maintaining a scientific quest and liberating Science from all forms of ideology that are imprisoned. For Haught, religious-based searching would lead to higher awareness than the materialist worldview that stops searching on the material realm only.

When Haught states that Religion support Science with the pattern of confirmation, then the question arises is "what does underly it all?" Whether the building could justify that Science has a closed connection with Religion? In the view of Haught, Science can not fulfill itself (self-sufficient) in conducting scientific development. Science always refers to or is rooted in the faith:"Science, to be more specific, can not even get off the ground without rooting itself in a kind of a priori "faith" that the universe is rationally ordered totally of things." (Haught, 1995, p. 23).Therefore, Science can not stand alone, but it depends on the permanent entity. Haught defines the permanent value as a source of inspiration that eventually turns on and develops further scientific exploration. Things that are fixed and always underlying Science is 'faith' that the universe is orderly (and its accompanying laws) and rational. To build an integrative building between Science and Religion, Haught offers epistemological reading that Science is always rooted in the faith from which Religion gives a very clear definition. Science would not want to say that its existence depends on a permanent order in the universe. For Haught, 'faith' gets meaning when associated with Religion as the 'spirit' of faith. Similarly, Ogden understands Religion as a 'guarantor' (reassurence), as the most essential part to build confidence when the spirit is gone (Haught, 1984, p. 4).

In addition to its function as the first category of the scientific process, faith is the entity that is fundamentally capable of carrying humans toward a comprehensive knowledge (overall). This happens because of the limited human ability to understand the reality requiring the entity that place faith as a source of knowledge. As stated by Haught (1984,p. 7), "Faith is an attitude of acknowledging the limits of comprehension and of opening ourselves to being comprehended by that which transcends us".

Therefore, Science would not be able to achieve the comprehensive nature when limiting itself in the realm of sheer material. Science should involve knowledge that comes from Religion and God as a manifestation of 
the nature of transcendence. But Science tends to regard such entities as the faith as knowledge that can not be decomposed by the principles (methodology) Science. Haught convinces that the presence of faith as a form of metaphysical worldview inspired by Religion would lead to a deep understanding of evolutionary events. For him, any concept and understanding of Science, a scientist is always shaped by the general vision of reality that he has. ".... This theological Metaphysics is a superior to the materialist alternative," Haught says (Barbour, 2000, p. 54). So the Haught's proposal is to make theology (Religion) as the foundation or roots of Science. Above this basis, the integration can be realized. If it is described as the body of a tree, then theology (Religion) is the root, while the stem is the structure of Science.

After seeing the integration patterns that have developed between Science and Religion, Haught tries again more concretely by examining the integration on the theory of evolution and Religion which he calls theology of evolution. It is a theological response to the lack of reviews in evolution. In many religious view, the theory of evolution is accused as the most dangerous force for the existence of Religion. But behind the concerns, there are still very few critics to bring the theory of evolution in theological perspective. Here, Haught boldly offers a very explorative readings, it is how to lead the theory of evolution in order to charge theology.

Haught's criticism leads him to the theory of evolution, because of pretty extreme evolution development. Currently, biology is a fortress of materialism. As quoted by Haught, Russell says that Darwinism is the perfect incarnation of materialism theory (Haught, 2003, p. xii). Furthermore, dramatically Darwin's theory, in contrast to other modern scientific advancement, has pushed Religion placed solely in the illusion of space that has no roots of truth. Besides, there is no theory that is so threatening human understandings about the goal of universe except the theory of evolution.

Haught's concern is how to read or interpret texts in the light of Darwinian scripture (2003, p. xv). He set out in God After Darwin (Haught, 2000 , p. 121) that biological evolution is not only not against Religion but more than that it is also a valuable gift to theology. In a very convincing words, Haught asserts:

"Darwin has gifted us with an account of life whose depth, beauty, and pathos-when seen in the context of the larger cosmic epic of evolutionexpose us afresh to the raw reality of the sacred and to a resoundingly meaningful universe" (Haught, 2000, p. 135).

A part of what makes evolution is not in harmony with the idea of God and not as shocking news of Darwin's natural selection process, but due 
to the inability of theology reflects deeply about the plight of divine dimension. Understanding of God as the source of order which determines all events in the universe is no longer able to give satisfaction. Haught offers readings about God not merely as an agent who arrange everything to run accordingly to its function, but he also understand as a form of appearance of disharmony. For Haught, theory of evolution is a light that can illuminate and ultimately recognize a deeper meaning of Religion and God. In fact, he calls the theory of evolution as the deepest intuition because the light of evolution would bring theology to stepping further in understanding the ultimate reality'.

Haught describes the relation between Religion and evolution as an 'engagement' in which Darwin's thought is seen not as dangerous idea to understand theology. Instead, he is placed as a source to reflect the meaning of life, God, and universe. There are two effects that significantly affect theology (Haught, 2000, p. 159): first, the emergence of a new interpretation of the character of "natural theology" (a search for evidence of the existence of God in the universe). The real form of natural theology is the emergence of theory of 'intelligent design', the theory states that the creation process has been designed in such a way that raises life. Therefore, Haught focuses his great attention to the second effect, 'the evolutionary theology', one concept that is enriched because of its encounter with the theory of evolution as an understanding about divine power. Haught uses theology process to make sense of the process of evolution where evolution comes as an early form of creation because of the power of God and the actions taken against the world in a persuasive love rather than forcing power. God's power is not coercive but inviting, as if the force, it would be contrary to the very nature of love. From here, it is clearly known that the figure Haught is a theologian trying to integrate the Science (theory of evolution) and Religion.

\section{The Integration of Science and Religion in The Perspective of Golshani}

At the beginning of each book written by Golshani, he always starts with the assertion that Islam does not distinguish between Science and Religion. It is because each oriented to understand God. God is the center of all human activities, although the activities are not in the form of formal worship, but when it becomes the cornerstone and main purpose of Science, then the Science is to have an equal footing with Religion (2003, p. 39). Golshani looks for this activity, as a physicist, as a part of worship.Then in his view there is no conflict or independence in Science and Religion (Richardson, et al., 2001, p. 121). 
This understanding departs from a hadith which states that every Muslim is obliged to seek knowledge. According to Islam, the criteria of valuable knowledge or not depends on its usefulness and capacity to deliver an understanding towards God. Therefore, any form of knowledge that is useful and has the capacity to reach God is a part of worship and of course it is a must to learn (Golshani, 1997, p. 5).

Science has brought a number of functions for mankind and to encourage people to be more familiar and closer to their creator. Scientific significance for Muslims, among others, are: first, Science is able to improve understanding toward God. Second, Science is effectively able to develop the Islamic civilization and to implement the ideals of Islam. Third, Science serves as a guide to mankind in the face of life's challenges (Golshani, 2003, p. 49). If the presence of Science covered by such above understanding, no doubt he is not opposed to Religion, even Science is part of the Religion itself. With it, Science is also being sacred and away from the values that are contrary to Religion (divinity). Diverse knowledge is not foreign to each other because of the way, each tries to make sense of God's creation that spreads widely in this universe.

Golshani (2003, p. 163) defines Science as a tool to understand natural phenomena whic is used to enrich or deepen the knowledge of the people who believe in God. There are more than 750 verses in the Qur'an that mention about natural phenomena and most of them are in the form of an order to learn and reflect on this phenomena. In the perspective of the Qur'an, phenomena occurring in the universe can not be separated from the existence of God. Therefore, God must always be the end point of the process of scientist reflection. Knowledge of human creation, the heavens and the earth is an important part of God's presence. Golshani (2003,p. 165) cites the following Qur'anic verse:

"And one of His signs is the creation of the heavens and the earth and the diversity of your tongues and colors; most surely there are signs in this for the learned (QS. Ar-Rūm: 22)".

Science in Gholshani's view must always be connected with divinity entity that encourages a scientist to know his creator. He also affirmed that the statements include in the Qur'an is not a detailed description of natural phenomena, 'Scripture is not an encyclopedia of Science,' says Golshani. Scriptural descriptions of the process of day-poor, rain, and human creation are signs of God's order for humans to reveal these phenomena (Golshani, 2001, p. 126).

Golshani looks at the phenomenon of separation of Religion from Science (in the Islamic world) to the emergence of Western Science (starting 
from the Renaissance) to infiltrate the Islamic world. While until the end of the first millennium, the philosopher and physicist Avicenna does not do the separation between Mathematics, Physics, and Theology. Philosophy in the view of Golshani is not only limited to the region of ratio or the mind, because to be able to understand God, it is needed another way, namely revealation. In other words, there must be a combination of the two domains in order to achieve the goal. As one who deals with Physics, Mehdi Golshani acknowledges that modern Science has given wider space to increase awareness of the presence of the planner (master mind).

For Golshani, the important thing is cautious on scientific discoveries that interprete empirically or materialistically. Whatever the form of scientific discovery: the big bang theory, the theory of evolution, and so forth, should be integrated with the metaphysical framework that is consistent with the philosophy of Islamic worldview. He (Golshani, 2004, p. 125) says:

"Scientific knowledge can reveal certain aspects of the physical world; but, it should not be identified wint the alpha and omega of knowledge. Rather, it has to integrated into metaphysical frameworkconsistent with Islamic worldview".

Golshani's anxiety about modern Science which tends to have conflict with Religion is when the process of Science interpretation does not involve the metaphysical framework of Islam. Therefore, the function of Religion for Science is as a medium to interpret scientific data. This involvement is important to avoid negative impacts posed by the interpretation of scientific materialism that provide distance from value judgments.

The emergence of tendency of scientists by not discussing Metaphysics in their works begins when Modern Science began to praise absolutely empiricism as the most primary ways in the knowledgeable process. Empiricism believes that the empirical data is the only source of knowledge, so that Science should issue any Metaphysical concepts because it is not rooted in sensory experience. This view has been dominating the first half of the community of scientists from the late 20th century to the present. The influence is still strong in the academic world. But in the last 20 years, it is observed that empirical approach is superficial and not supported by properly study of the history of Science.

For Golshani(2005, p. 21-22), nothing is pure tangible empirical Science, because in every time of interpreting experimental data and even when testing the accuracy of the data, it always depends on the initial conception (preconception) and the scientists assumption. Einstein also said that the fundamental concepts and postulates of Science can not be referred to the sensory experience or induction process, but it can be traced in the 
human mind with every imagination and motivation owned. Golshani rejects the notion that a theory as a direct result of experimentation. Such inference can not be directly from the experiments but it can verify the truth. Agreement between theory and experimental facts is not necessarily so, because it is logically an inference that can be drawn from a variety of premise.

Golshani's tracking shows the presence of Metaphysics in an attempt to bring a lot of leaders in Physics for a more detailed description of the theories that can be expressed in his book From Physics to Metaphysics. All of which confirms that the Science building is not solely derived from empirical data and experimentation, much of it necessarily involves assumptions, preconceptions and presuppositions of the scientists. This space is often not considered by Science that has already been absolute in empiricism, as the most valid reading patterns (Golshani, 2004,p. 49).

It has been described that Metaphysics does not conflict with Science, but whether the function of Metaphysics? Metaphysics in the thought of Golshani is not only interpreted as aspects of non-physical involved in Science, but he makes a more specific categories by locating preconceptions or outlook on life as a metaphysical realm. In the presumption that every imagination, values, and outlook on life intensely involved. All forms of the trend and the way of life rooted in or based on Religion. Here it lies Religion as a reference of the Metaphysics building that finally put it as the basis of the Science (Bagir,et. al., 2005, p. 58). Integration between Religion and Science become interwoven when metaphysical framework becomes the foundation of Science. The connection of Science and Religion has become possible due to the Metaphysics that underlie integration contains values or Religion views.

\section{The Integration Form of Science and Religion (Islamic Sciences)}

The real form of the integration of Science is built by Metaphysical presumptions that eventually lead to the presence of Religion suggesting that religiosity charge of someone become a crucial entity. If a scientist is a Muslim, the Islamic values that he has would influence the orientation of Science. This is where the importance of Islam as a worldview that participating in the construction of Science. Golshani offers Islamic Science, as a concrete form of union that puts Science and Islam as a complementary building. An example that arises is how to define precisely what the meaning of Islamic Sciences is. Golshani rejects the view that Science is value-free, so it might not include the concept of Islamic Science to be an independent building. Thus, he does not agree with many people since he refers to the Islamic Science as a discipline which could address to the miracle of Qur'an 
or Islamic tradition as a way to prove the existence of God. In addition, it is not true that Islamic Science emerged because it is only viewed that Science came from the Muslim scientists.

He believes in the workings of Science, such as the selection of theory, which relies heavily on what he calls a Metaphysical presumption of scientist. In his explanation, Metaphysical commitment also plays a very important role in the development and interpretation of a theory. Here, it lies where the value of a person's Islamization greatly affecting work patterns and how interpretation is carried out. So, Golshani (2004, p. 51) asserted: "If Science was simply based on simple observation, then there would be no difference between Islamic or non-Islamic Science."

Metaphysical outlook of Science about nature or physical reality clearly affects theory or scientific outlook made. And it is shaped by philosophical or religious commitments owned by scientists. In Golshani's note there is a fact that religiosity ideas provide impacts to the action, selection process, and evaluation of a theory. This view brings him to the view that Islam should be an integral part of the development of Science. Here, Golshani calls Islamic Worldview as the key to know how Science is shaped by Religion. Golshani (2005, p. 82-87) mentions three elements of the Islamic World view affecting knowledge and Science in particular. These elements include:

1. Singular nature of God (al-taubid). This has resulted in the emergence of the concept of creation unity and the views associated with each other among the various creatures that exist on earth. Also with the knowledge, all forms of knowledge are a manifestation of the unity of creation or everything that exists on earth. Therefore, scientific quest must be synthesized for the realization of a harmonious world.

2. Faith in the supranatural and the limitations of human knowledge. This view confirms that reality consists not only of a physical nature alone, but there is a reality that is not covered by the human senses. Faith in the reality of the supranatural and human limitations will produce understandings at the level of sensory, non-sensory as well as certain infinite.

3. Commit to moral values. The development of Science must be accompanied by knowledge of ethics. Science without accompanied by ethical considerations will encounter a lot of problems. Ethics education becomes very important to cultivate moral concern and responsibility.

The three categories are the values in principle held by the Abrahamic Religions that show similarity of views between Islam, Christianity and Judaism. Therefore, Golshani (2004, p. 57) puts these characteristics in terms of 'theistic religion'. With the advance of Islam in the construction of Science, it does not mean that it would change the Science contruction that has been 
agreed upon by the scientific community. Therefore, he rejects the definitions of Islamic Science that comes out of the concepts he proposed, among other things; 1) the scientific activities (testing, observation, theorization) would be conducted in a new pattern; 2) Physico-chemical research should refer to the Qur'an and Sunnah; 3) entering the wonder dimensions of the Qur'an in Islamic Science; 4) Science returns to the old scientific theory; and 5) all forms of Science and Technology that emerged in the last century, must be halted (Golshani, 2004,p. 61-62).

This pattern also shows the totality of Science, where Science is not just made up of experiment and observation, but it is equipped with Metaphysical considerations that would make Science to become a comprehensive search. So complex realities that can not be captured only by the ability of human cognitive or sensory bit it must be also equipped by an understanding of immaterial realities that always underly human mind in interpreting something. This is where Islamic Worldview get the place.

\section{The Intersection of Haught's and Golshani's Thought in The Construction of Science and Religion}

In the context of the relationship of Science and Religion, Metaphysics lies the Science epistemological structure that serves as the foundation for the existence of Science. A concrete form of Metaphysics is 'faith'. Like a door, faith is the key that allows humans venture further into the house. Therefore, faith serves as the first step that must be passed to the secrets of reality. Through faith, human consciousness knows its limitations and the same time lead to the knowledge of higher dimension or depth dimension.

In scientific exploration, a scientist has to commit to the belief that "The universe can be understood (the universal is intelligible) or truth is worth seeking." According to Haught (2000, p. 111), the commitment of scientific belief has conformity to the vision of Religion. Furthermore, Science has a deeper meaning when it is paired with the context of Religion. Metaphysical theological framework would bring discoveries of Science more understandable (intelligible).

Haught clearly defines Metaphysics as a common vision to see something, so he puts Religion as a building that could fit into it. Religion could bring general principles influence on how Science should be interpreted. On the other hand, Haught claims that Religion is the most powerful entity could be a framework of Science (evolution) disproved by Richard Dawkins. For Dawkins(2004, p. 21), since the discovery of the theory of evolution, Religion has no longer a significant place in the building of Science. He interpretes natural selection as a Blind Watchmaker, it is called blind because it is not looking forward and not struggling that is being 
evidence of no role of the Religion there. Religion views that the universe aims where everything is in God's authority that is no longer significant (Illis, 1996, p. 266).

For Illis (1996, p. 269) what Dawkins has been out of from the realm of Science because Illis has done metaphysical-philosophical justifications. It is also alleged by Haught (1995, p. 17), where that sort of thing is categorized as scientism. The affirmation of Haught even his understanding of Science must be accompanied by a theological concept arise because for him, the theological building is superior or satisfying than explanations offered by Materialism. There are two fundamental things why Metaphysics with the theological charge has a deeper frame. It is an understanding of power and the dimension of power when it is connected to the autonomous nature of the evolution of science. Here, he gives an example of the character of God's humility as a theological character that allows true novelty that arise spontaneously. This is contradictory to the Materialists that view the phenomenon interpreted deterministically. Haught also does not agree with the view that the universe as an eternal and permanent (fix) stretch. From the above discussion, it shows that the theological building offered by Haught is a theological building inspired by the theory of evolution so that the unevolutive theological building is not being an ideal theological building. It is usually reflected in the form of 'intelligent design'.

The view of Haught about the integration foundation of Science and Religion has similarity to Golshani's thought, mainly about the meaning and function of Metaphysics. Golshani'sis often called Metaphysics which is in line with worldview, a world that has the same meaning toa general vision or perspective.

A worldview is a framework within our minds operate. It includes our metaphysical and epistemological presuppositions about God, the universe and humanity. Our worldview affects our decisions, priorities, values and goals. It brings our thoughts to a unified whole (Golshani, 2005, p. 82).

The thing that becomes main concern of Golshani is Science that can never be neutral without being influenced by the worldview of scientist. He explains in depth how the Science is not neutral or value-free. Science is always influenced by the trends that are owned by a scientist. Here, he categorizes the space as a metaphysical presumption. He denies the suggestion that says if Science can be entered by ideology, Religion, or other values that are beyond the structure of Science, then Science is not universal anymore. For Golshani, definition for universal Science or neutral Science does not 
exist in principle, if there is then the Science which is limited only to the process of mere description. Golshani $(2005$, p. 88) says:

.... Science could be a universal enterprise, if the findings of empirical Science were not extended beyond their context of discovery and if

Scientists stopped at the description of the phenomenon.

In line with the views of Golshani who perceives Science can not stand alone especially in the process of interpretation or verification, Kuyper asserts the same thing. For Kuyper, on the level of representation, a view of life is not involved or neutral, but when it is associated with the decomposition of theory, then it involves interpretive assumptions which are outside of the body of Science. It is the metaphysical dimension worldview (Religion), which shape the construction of Science. In fact, he puts the Bible as a way of life that should form the Science because it (Religion) does not create conflict with Science, especially in the realm of theoretical aspect. The most fundamental of similarity that exists is that Golshani and Kuyper put commitment (guiding commitment) as an entity that has a big contribution early in the development of Science (Goshlani, 2005, p. 126).

Therefore, Haught and Golshani in the context of integration basis tends to have a lot of similarities in common. The fundamental similarity of the two figures are both using the metaphor of 'roots' to combine Science and Religion. Haught tries to take root of Science on the religious views about reality. Similarly, Golshani puts the root Science in Religion views. In its position as the root, Religion gives assurance that nature which is being the study of Science is a rational natural, orderly, and has laws. Without the belief in the existence of law on a regular basis, there would be no conceptual fondation for development of scientific theories. here, they make Religion as the basis of scientific work (Bagir, 2005, p. 23).

\section{The Contribution of Haught and Golshani's Thought to The Existence of Islamic Higher Education (PTAI) in Indonesia}

From several common fundamental intersections, both integration view of Haught and Golshani can be also elaborated substantively in a more academic-operational dimension as an effort to strengthen the existence of Islamic Higher Education (PTAI) in Indonesia. Islamic Higher Education (PTAI) as witnessed in recent years has been experiencing an outstanding academic confrontation with the development and progress of worldly Science and technology which 'force' it to make the very resistense process of metamorphosis to balance itself with the development of Science and technology (IPTEK) as similarly to the efforts of continuing to 'live' in the arena of higher education world competition that is getting hilarious. On the other hand, the two men's thought is very possible to be adapted in the 
academic arena of Islamic Higher Education which substantively has similar characteristics so as to be achieved, namely the development of Science and Religion that is more integrated, regardless of the spirit of their different religious background.

The Change of a number of State Islamic Higher Education (PTAIN) to become State Islamic University (UIN) and so many Islamic Higher Educations (including Private Islamic Higher Education/PTAIS) that provide public courses, such as Psychology, Sociology, Engineering and others during this postscript is viewed as 'deviant' from Islamic Higher Education philosophical foundation itself as a proof that the process of metamorphosis has been 'infected' Islamic Higher Education (PTAI) in Indonesia (Thoyib, 2012, p. 48).

Regardless of substantial debates in the academic arena, according to the author there are some urgent things of the two men's thought which can be served as the basis of philosophical and academic foundation for Islamic Higher Education in Indonesia. This is to strengthen the process of metamorphosis to fit the existing of Science and technology development, without losing identity themselves as 'Islamic morality and social-cultural institution', as once defined by Azra. Some fundamental things are (Azra, 2000, p. 51);

1. The development of scholarly study in Islamic Higher Education (PTAI) always allows to continue to follow the development of Science in the context of globalization of Science which continuosly follow the growth that relies on the development process of philosophical values of Islam so as to the spirit entities of Science and technology developed not out of the corridor of religious ethics. It is as the basic theory of evolution theology as defined by Haught, who is viewed relevantly in accordance with the author; its is seen as Islamic Micro Designof the integration of Religion and Science. To strengthen the development as well as to enrich the wealth of the scholarly study, it is also necessary to explore a number of knowledge independently associated with the Science includes in the Qur'an and the Hadith, or the reality of Sunnatullah that would allow the increasing number of Science (new discoveries of Islamic Sciences) that will be born from the Islamic Higher Education world (PTAI) as a basic view of Islamic Science theory initiated by Golshani, which the author considers as Islamic Macro Design. With the integration of two approaches, it would allow Islamic Higher Education in Indonesia to not only be able to survive and exist in global competition arena of higher education, but more than that would be able to be a primary locomotive of Islamic Civilization Renaissance that would be born in Asia, as many pointed out by Islamic and the West thinkers, such as Fazlur Rahman, Rajak Ahmad al- 
Faruqi, Naquib al-Attas, Daniel S. Lev, and so forth (Zuhdi, 2012, p. 104).

2. The efforts of development of Science and Religious Studies integratively on Islamic Higher Education (PTAI) in Indonesia, need to be done on the basis of the values of religious morality that 'live' in each of these studies perpetrators. In that context, of course, all components of the existing academic community of Islamic Higher Education, especially the leaders and teachers as well as the basic theory of Haught and Golshani stressed the importance of perpetrators religious belief as the root of all the processes and findings of Science around there. With such principles, Science and Technology developed by Islamic Higher Education in Indonesia would not always only live in the hearts of its academic community but more than that it would form the high morality civilization because based on strong religious foundation. As a matter of fact, the process of metamorphosis has been done by Islamic Higher Education as being State Islamic University (UIN) also left a number of issues and concerns that quite fundamental. Of which, with the change, UIN is being considered as institution that increasingly tries to touch values of religious praxis, even though it is basically the knowledge of Religion born from the institution itself (Zuhdi, 2012, p. 128). On the other hand, with that change, an issue raises concerning that public interest against the Religion faculty also undergo a metamorphosis that actually is contradiction, where Religion faculty is seen as 'Second Class', not the top choice, as a result, many Religion faculties are forced to 'shut down' due to the absence or lack of students. These issues and concerns should be taken seriously by the Islamic Higher Education (PTAI) in Indonesia by trying to formulate ideas of integration values of Science and Religion from Haught and Golshani in the application of scientific development in the institution. Finally, Islamic Higher Education in Indonesia is not only large in quantity, but it is balance in the quality as well.

3. As a paradigm of Golshani and Haught who see Science is value-free dimension (neutral), then the efforts to develop Science and Religion in Islamic Higher Education should be integrated since the beginning has been based on religious values, so that Religion would be the soul for Science construction and Technology that would be explored and developed by Islamic Higher Education. With such view, Islamic Higher Education (PTAI) is not only able to develop Science and technology in a more innovative, but also able to establish 'Islamic brand design' of the characteristics of Science and Technology development, as efforts to strengthen the existence of Islamic Higher Education (PTAI) in 
Indonesia as well as a representation of the Islamic civilization in Southeast Asia that have its own characteristics, without losing the competitive values and excellence that are expected to be able to speak a lot in the context of higher education global competition.

\section{CONCLUSION}

Haught 'sees' and 'interprets' the integration of Science and Religion as 'two faces of epistemology' that are touching each others and bringing out the enlightening complementation. This shows how Science and Religion dig into the depth so that each can meet in the same estuary. While, Golshani does not try to offer movement space for Religion. For him, Religion occupies an area of metaphysical worldview that does not need to accelerate with the discoveries of contemporary Science. Haught's courage for elaborating evolution for Religion compatibility is a kind of courage because it necessitates the reading of theological shift. While Golshani judges Religion into the corner of conducting scientific orientations as well as guidance in applying Science in accordance with Islamic values. Haught's integration model spawned from evolution theology that is a building of theological epistemology 'faceless' of modern reconstructionists who take Religion so much for its sake of conformity with the development of Science. In other words, theology is a barometer of scientific theories. While the integration model of Golshani births 'theology of structural integration or Islamic Science' where there is no Science that is neutral or value-free, Science has always been shaped by the metaphysical foundation of a scientist. The inclination to incorporate Islamic entity in the structure of Science. The Contribution of Haught and Golshani may serve as a philosophical foundation in the effort to strengthen the existence of Islam Higher Education (PTAI) in Indonesia, through; 1) the development of scientific discourse in the Islamic Higher Education should be carried out by continuosly following the development of Science and globalization of Science relying on the development process of Islamic philosophical values. Thus, the spirit entity of Science (technology) is not out of the corridor of religious ethics as a new discovery of Islamic Sciences in the Islamic Higher Education (PTAI); 2) the efforts of development of Science and religious studies should be implemented integratively at Islamic Higher Education (PTAI) in Indonesia, which are needed to be done on the basis of the values of religious morality that 'live' in both perpetrators of these studies; 3) the efforts of development of Science and Religion should be implemented integratively in Islamic Higher Education (PTAI) in Indonesia.Since the beginning, the efforts should have been based on religious values, so as to the Religion would become the spirit of constructing the integrated model of Science and technology that would 
be explored and developed by Islamic Higher Education in Indonesia genuinly.

\section{BIBLIOGRAPHY}

Azra, A. (2000). Pendidikan Islam, Tradisi dan Modernitas Menuju Milenium Baru. Jakarta: Logos.

Bagir, ZA.(2005). Islam, Science and 'Islamic Science': How to Integrate' Science and Religion.In Science and Religion in Post-Colonial World. Australia: ATF Press. 2005.

Barbour, IG. (2000). When Science Meets Religion. New York: Harper SanFrancisco.

Dawkins, R. (2004). "Is Science a Religion?" Published in The Humanist on line, January/February, Accesed on December $6^{\text {th. }} 2004$.

Golshani, M. (2001). The Holy Quran and The Science of Nature. New York: Global Scholarly Publication.

Golshani, M. (2003). From Physics to Metaphysics. Iran: Institute for Humanities and Cultural Studies Publication.

Golshani, M. (2004). Issues in Islam and Science. Tehran: Institute for Humanities and Cultural Studies (IHCS).

Golshani, M. (2005). "Sacred Science vs Islamic Science.” In Zainal Abidin Bagir, ed. Science and Religion in a Post-colocial World. Australia: ATF Press.

Haught, John F. (1984). The Cosmic Adventure: Science, Religion and the Quest for Purpose. New York, Ramsey: Paulist Press.

Haught, John F. (1995). Science and Religion: In Search of Cosmic Purpose. New York: Paulist Press.

Haught, JF. (2000). God after Darwin A Theology of Evolution. USA: Westview Press.

Haught, JF. (2003). Deeper Than Darwin: The Prospect for Religion in the Age of Evolution. USA: Westview Press.

Illis, GFR. (1996). 'The Thinking Underlying the New 'Scientific' Worldvienss". Dalam Russel, Robert John et al.eds., Evolutionary and Molecular Biology. USA: The University of Notre Dame Press.

Rahman, F. (1996). Islam and Modernity. New York: Chicago Press.

Thoyib, M. (2012). Manajemen Mutu Pendidikan Islam Kontemporer: Teori, Aksi dan Mutu Pendidikan Islam dalam Konteks Internasionalisasi Pendidikan Indonesia. Jakarta: Kemenag RI.

Zuhdi, I. (2012). Perguruan Tinggi Islam di Indonesia: dari Realitas ke Idealitas. Surabaya: Bintang Pustaka. 